\title{
Polymorphism of proteins in the pretransferrin (Ptf) subregion of blood serum and reproductive performance of turkeys*
}

\author{
A. Brodacki ${ }^{1}$, J. Jankowski ${ }^{2}$ and A. Faruga ${ }^{2}$ \\ ${ }^{\prime}$ Department of Biological Basis of Animal Production, Lublin \\ Agriculture University, \\ Akademicka 13, 20-934 Lublin. Poland \\ ${ }^{2}$ Department of Poultry Science, Olsztyn University of Agriculture and Technology, \\ 10-718 Olsztyn 5, Poland
}

(Received 23 September 1994; accepted 16 February 1995)

\section{ABSTRACT}

Serum proteins from $232 \mathrm{~J}-11$ and $242 \mathrm{~J}-22$ turkey hens were separated by polyacrylamide gel electrophoresis. The genotypes of proteins from pretransferrin subregions (PII) were the basis for dividing the hens into groups $\mathrm{A}, \mathrm{AB}$ and $\mathrm{B}$. The average level of reproductive parameters was estimated in each group: age at sexual maturity, number and weight of eggs, length of laying period (days), egg fertility, hatchability of set and fertile eggs and body weight of hens in the 30th and 56th weeks of life.

Birds with $\mathrm{Ptf}^{\mathrm{B}} / \mathrm{Ptf}^{\mathrm{b}}$ genotypes were characterized by a significantly lower value of reproductive

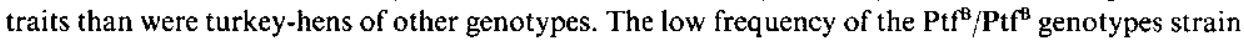
$\mathrm{J}-22$ was found.

KEY WORDS: turkeys, blood serum, polymorphism of proteins

\section{INTRODUCTION}

Genetic polymorphism of transferrins and alkaline phosphatase in the serum of turkeys was found by Ranjan and Pingel (1973) using electrophoresis on starch gel. In the same medium, Kierek-Jaszczak (1976) carried out electro-

\footnotetext{
* This study was financed by grant No. 503679101 from the Committee for Scientific Research
} 
phoresis of blood serum proteins, egg content and seminal fluid of 149 Bronze Wide-Breasted turkeys. She found this group of turkeys to be monomorphic with regard to these proteins. However, on polyacrylamide gel, on which considerably more bands can be obtained than on starch gel, Schellner (1970) separated structural serum proteins of 12- and 19-week-old turkeys into 27 bands. He determined the rate of migration of individual fractions and did not find major differences in the number of bands or their migration rate. Studies on the variation of blood serum proteins in the egg content, thigh and breast muscles of White Broad Breast turkeys were made by Brodacki et al. (1988; 1989 b,c,d).

Since traditional methods of animal selection often lead to decreased breeding progress, attempts are therefore being made to find genetic markers of performance parameters that can be used in selection work. Such studies have not been performed on turkeys, but were, however, conducted on chickens by Abaza (1991) and Abaza et al. (1991). They found a correlation between blood group phenotypes and the number of laid eggs, early age of maturation and body weight. Hartmann et al. (1986) showed a correlation between resistance to Marek's disease and genes of the group arrangement. Sheldon (1980) presented studies concerning attemps to find new indices which would make it possible to determine the usefulness of animals in further breeding work in the early period of ontogenetic growth.

Brodacki et al. (1989a) showed, in the goose, a relationship between the genetic forms of slow migrating prealbumin and body weight, meat and fat weight in the carcass.

The objective of this paper was to determine the inheritance pattern of proteins from the subregion of serum pretransferrins and to find a relationship between polymorphic forms of these proteins and reproductive performance of turkeys.

\section{MATERIAL AND METHODS}

The study was carried out on 232 turkey-hens of the J-11 strain and 242 turkey-hens of the J-22 strain of White Broad Breasted from generation $\mathrm{G}_{1}$ and 185 and 107 turkeys from generation $\mathrm{G}_{2}$. Blood was sampled from the wing vein and left to clot in test-tubes, after which serum was obtained by centrifugation. Blood serum proteins were separated by horizontal electrophoresis on polyacrylamide gel according to Gahne et al. (1977) modified by Głuchowski et al. (1985). The following parameters were registered in the turkey-hens from generation $\mathrm{G}_{1}$ : body weight at the age of 30 and 56 weeks, age at sexual maturity, number and weight of eggs, length of laying period (days), egg fertility, 
hatchability of set and fertile eggs. The turkey-hens from generation $\mathrm{G}_{2}$ were not in selection flocks, so their reproduction traits were not registered.

The turkey-hens were divided into three groups depending on the genotype of proteins from the subregion of pretransferrins (Ptf). Group A included birds with the genotype $\mathrm{Ptf}^{\mathrm{A}} / \mathrm{Ptf}^{\mathrm{A}}, \mathrm{AB}-\mathrm{Ptf}^{\mathrm{A}} / \mathrm{Ptf}^{\mathrm{B}}$ and group $\mathrm{B}$ - those with $\mathrm{Ptf}^{\mathrm{B}} / \mathrm{Ptf}^{\mathrm{B}}$. The differences between the average values of reproductive parameters were verified with the F-Snedecor test based on analysis of variance and with the $\mathrm{X}^{2}$ test.

\section{RESULTS AND DISCUSSION}

Figure 1 presents a photo and Figure 2 a diagram of the electrophoregram of turkey serum proteins and phenotypic variants observed in the pretransferrin region $\left(\mathrm{Ptf}_{1}\right)$. The electrophoregram contains the following regions and subregions of serum proteins: prealbumins $(\mathrm{Pa})$ divided into fastmigrating $(\mathrm{Pa}-\mathrm{F})$,

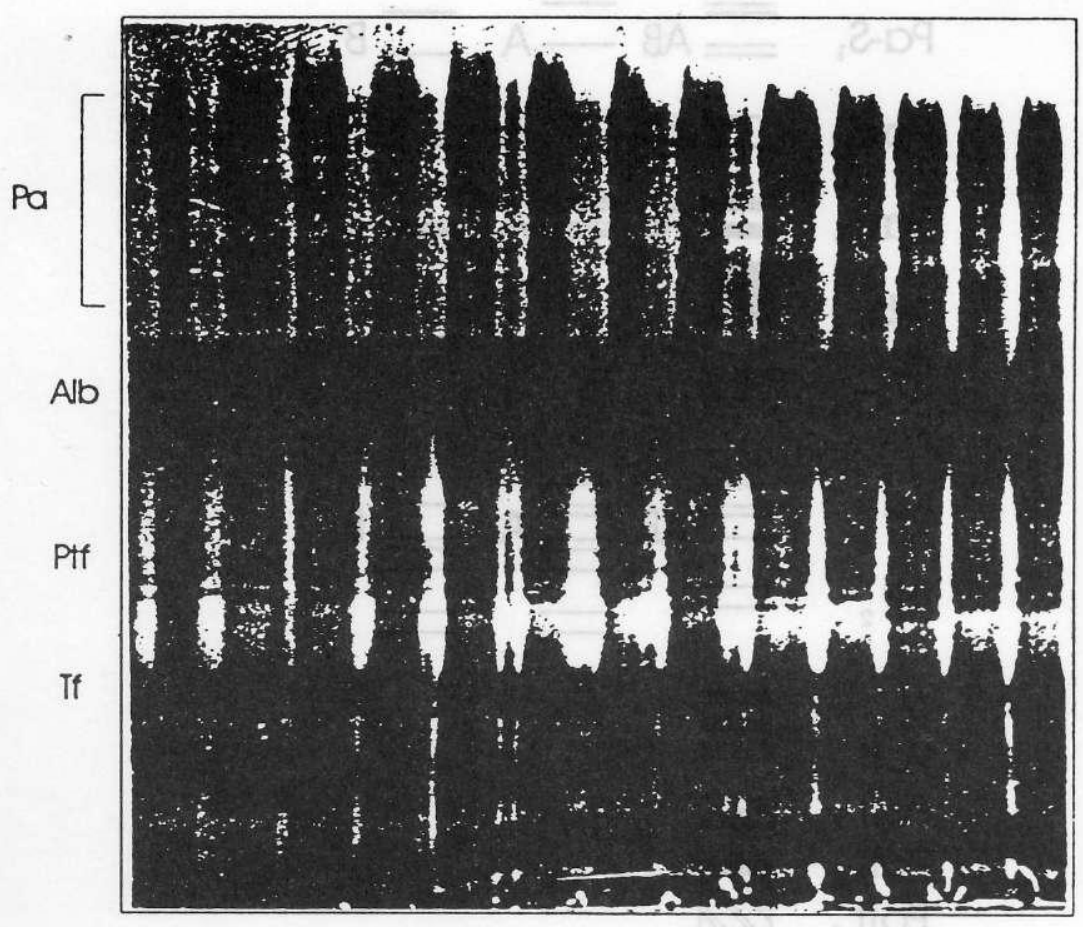

PIf $A B \quad A \quad A \quad A B \quad A B \quad A \quad A \quad A B \quad A B \quad A \quad B \quad A \quad A$ 
Pa-F $\equiv$

Pa-M,

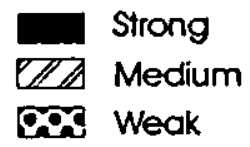

${ }_{\mathrm{Pa}-\mathrm{M}_{3}=\mathrm{A}}^{\mathrm{PaB}} \mathrm{B}$

$\mathrm{Pa}^{-\mathrm{M}_{4}}=\mathrm{AB}-\mathrm{A}-\mathrm{B}$

$P_{P} S_{1} \rightleftharpoons A B=A$ 二

$\mathrm{Pa}^{-\mathrm{S}_{2}}=\mathrm{AB}-\mathrm{A}-\mathrm{B}$

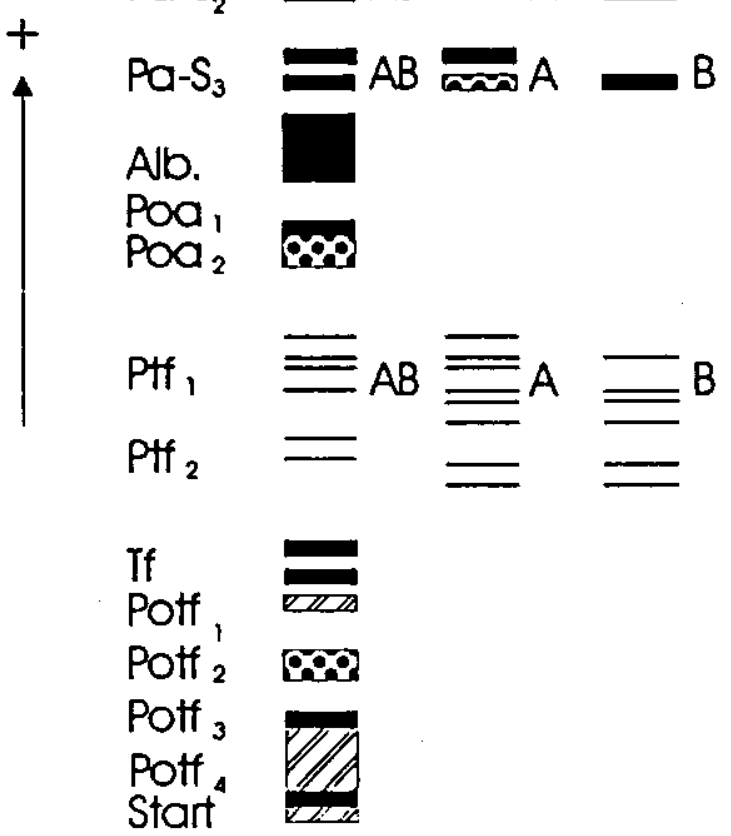

Figure 2. Diagramatic presentation of clectrophoregram of serum proteins in turkeys 
medium (Pa-M) and slow-migrating (Pa-S), albumins (Alb), postalbumins (Poa), pretransferrins (Ptf), transferrins (Tf) and posttransferrins (Potf).

Three phenotypes were observed in the Ptf subregion in the examined turkeys: Ptf-A, characterized by four fast-migrating bands; Ptf-B with four slow-migrating bands and Ptf-AB with six bands. Table 1 presents the protein phenotypes in this region in the parents and offspring of the turkeys under study. The chi 2 test showed that the actual number of observations in individual phenotypic classes in offspring was as expected both for individual matings and for the whole examined material. It follows from the data in Table 1 that the proteins from subregion Ptf are determined by one pair of autosomal codominant alleles, however, genotype $\mathrm{Ptf}^{\wedge} / \mathrm{Ptf}^{\wedge}$ determines the presence of four fast-migrating bands in serum, $\mathrm{Ptf}^{\beta} / \mathrm{Ptf}^{\sharp}$ four slow-migrating bands and $\mathrm{Ptf}^{\wedge} / \mathrm{Ptf}^{\beta}$ - six bands.

Tables 2 and 3 present characteristics of performance of the turkey-hens from strains $\mathbf{J}-11$ and $\mathrm{J}-22$ that differ in respect to the genotypes determining proteins from the subregion of serum pretransferrins.

The turkey-hens from strain $\mathrm{J}-22$ with genotypes $\mathrm{Ptf}^{\mathrm{f}} / \mathrm{Ptf}^{\mathrm{B}}$ reached maturity significantly later than the remaining birds, moreover, they laid 28 eggs fewer and their egg-laying period was 77 days shorter than that of the turkey hens with genotype $\mathrm{Ptf}^{\mathrm{A}} / \mathrm{Ptf}^{\wedge}$. The turkey-hens with genotype $\mathrm{Ptf}^{\wedge} / \mathrm{Ptf}^{\mathrm{B}}$ had intermediate trait values between those of groups A and B, and they differed significantly only in the number of eggs ( 9 fewer eggs) from the birds with the $\mathrm{Ptf}^{A} / \mathbf{P t f}^{A}$ genotype. In

TABLE 1

Distribution of pretransferrin genotypes in the progeny from different mating groups

\begin{tabular}{|c|c|c|c|c|c|c|c|}
\hline \multirow[t]{2}{*}{ Strain } & \multirow[t]{2}{*}{ Parents } & \multirow{2}{*}{$\begin{array}{l}\text { Number } \\
\text { of matings }\end{array}$} & \multirow[b]{2}{*}{ A } & \multicolumn{3}{|c|}{ Orrsprings } & \multirow[b]{2}{*}{$\mathrm{P} / \mathrm{X} 2 /$} \\
\hline & & & & $A B$ & B & $?$ & \\
\hline \multirow{7}{*}{$J-11$} & $A \times A$ & $4 \times 8$ & 21 & - & - & 7 & \\
\hline & $\mathrm{A} \times \mathrm{AB}$ & $4 \times 7$ & 10 & 7 & - & - & $0.80-0.70$ \\
\hline & $\mathrm{AB} \times \mathrm{A}$ & $8 \times 17$ & 23 & 21 & - & 15 & $0.98-0.95$ \\
\hline & $A B \times A B$ & $9 \times 13$ & 6 & 15 & 7 & 5 & $0.90-0.80$ \\
\hline & B x A & $3 \times 7$ & - & 9 & - & 6 & \\
\hline & $B \times A B$ & $4 \times 8$ & - & 16 & 10 & 2 & $0.30-0.20$ \\
\hline & B $\times$ B & $1 \times 1$ & - & - & 1 & - & \\
\hline \multirow[t]{2}{*}{ Total } & & $33 \times 61$ & 60 & 68 & 18 & 39 & $0.80-0.70$ \\
\hline & $A \times A$ & $6 \times 12$ & 35 & - & - & 3 & \\
\hline \multirow[t]{3}{*}{ J- 22} & $\mathrm{~A} \times \mathrm{AB}$ & $1 \times 1$ & 1 & 1 & - & 1 & \\
\hline & $\mathrm{AB} \times \mathrm{A}$ & $5 \times 13$ & 19 & 18 & - & 5 & $0.70-0.50$ \\
\hline & $\mathrm{AB} \times \mathrm{AB}$ & $4 \times 7$ & 9 & 11 & 3 & 2 & $0.10-0.50$ \\
\hline Total & & $16 \times 33$ & 64 & 30 & 3 & 10 & $0.50-0.30$ \\
\hline
\end{tabular}

? - unidentified phenotype 
焉

崫

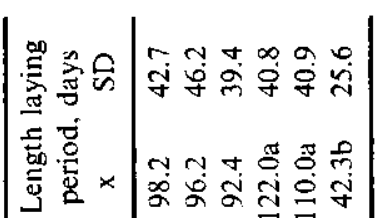

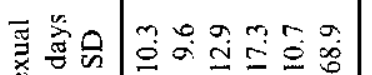

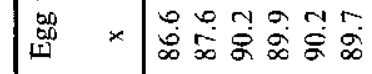

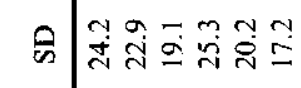

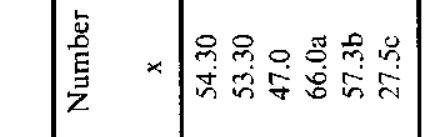

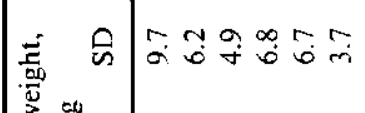

:

营

$\stackrel{8}{\infty}$

范

$\stackrel{\Xi}{\rightleftarrows}$

它

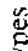

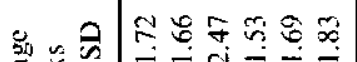

ㄴ.

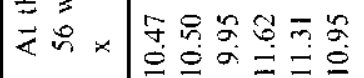

兵

E

$\stackrel{\text { co }}{\Xi}$

晏

$\stackrel{4}{0}$

豈

芒

$\therefore$

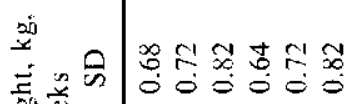

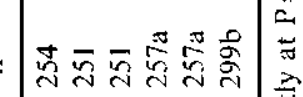

焉要

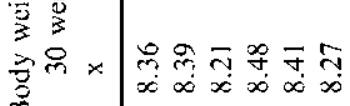

골

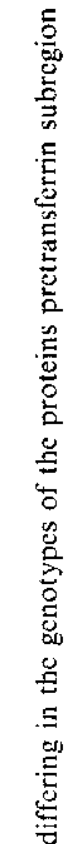

至

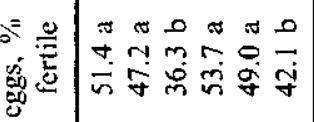

吾

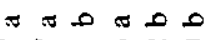

突

20

i

空

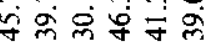

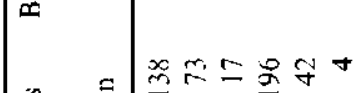

$\frac{0}{60}$ 
strain $J-11$ the relations were similar to those in strain $\mathrm{J}-22$, however, these differences were not statistically significant. With regard to the reproduction traits in J-11 strain, lower hatchability rates from set and fertile eggs (Table 3) were observed in $\mathrm{Ptf}^{\nexists \nexists} / \mathrm{Ptf}^{\mathrm{B}}$ females than in $\mathrm{Ptf}^{\wedge} / \mathrm{Ptf}^{\wedge}$ ones. The relations were similar in strain $\mathrm{J}-22$.

Due to the fact that the observed differences in mean values of the performance parameters in birds with different genotypes determining proteins from the subregions of pretransferrins were similar in both strains, one can imply that they are a pleiotropic effect of genes (although linkage cannot be excluded). The role of the proteins from the subregion of pretransferrins has not been explained yet, therefore it is difficult to find a functional connection between the phenotypic forms of proteins and the performance of turkeys. In chickens (Juneja et al., 1982), the proteins migrating in this subregion bind and transport vitamin $\mathrm{D}_{3}(12)$.

Despite the fairly high differences in trait values between birds with genotypes $\mathrm{Ptf}^{\mathrm{A}} / \mathrm{Ptf}^{\mathrm{A}}$ and $\mathrm{Ptf}^{\mathrm{B}} / \mathrm{Ptf}^{\mathrm{B}}$, removal from the flock all the birds with $\mathrm{Ptf} / \mathrm{AB}$ and $\mathrm{Ptf} / \mathrm{B}$ genotypes, that is total elimination of the gene unfavourably connected with reproduction traits, would only slightly increase the value of these mean general traits because of the low frequency of allele $\mathrm{Ptf} /{ }^{\mathrm{B}}$ in the examined turkey strains. A fairly high negative connection of allele $\mathrm{Ptf} /{ }^{\mathrm{B}}$ with the reproduction traits could have been the reason for its elimination from the examined turkey strains due to selection for performance, which explains its low frequency in strain $\mathrm{J}-11$ and $\mathrm{J}-22$ and its total absence in strain $\mathrm{J}-44$, characterized by a higher reproduction value (Jankowski, 1989).

\section{CONCLUSIONS}

A negative relatioship of allele Ptf/B with reproduction traits in strains $\mathrm{J}-11$ and $\mathrm{J}-22$ has been found.

Further studies on more numerous groups are necessary, however, because of the low frequency of the $\mathrm{Ptf}^{\mathrm{B}} / \mathrm{Ptf}^{\mathrm{B}}$ genotypes in the $\mathrm{J}-22$ strain.

\section{REFERENCES}

Abaza M., Ivancsics J., Papp M., 1991. Association of blood group genotypes with productive traits in native Hungarian yellow closed population. Proceeding 9th International Symposium "Aviagen". Smolenicc, pp. 124-132

Abaza A., Shebl M.K., Papp M., 1991. Immunogenetic studies on native Egyptian chicken breed. Proceeding 9th International Symposium "Aviagen". Smolenice, pp. 117-123 
Brodacki A., Gluchowski W., Smalec E., 1989a. Protcins from slowly migration prealbumin area and the performance of Cuban geese (in Polish). Prz. Nauk. Lit. Zoot. 35, 9.15

Brodacki A., Faruga A., Jankowski J., 1988. Electrophoretic variation of blood scrum protein in the turkey. Proceeding XVIII Worlds Poultry Congress and Exhibition. Nagoya, pp. 540-542

Brodacki A., Faruga A., Jankowski J., Plucinska B., 1989b. Turkey blood serum and egg protein. Proceeding 8th International Symposium "Aviagen". Smolenice, pp. 210-214

Brodacki A., Jankowski J., Faruga A., 1989c. Thigh muscle proteins in the turkey. Proceeding 8th International Symposium "Aviagen". Smolenicc, pp. 215-218

Brodacki A., Jankowski J., Faruga A., 1989d. Comparison of proteins in serum as well as in thigh and breast muscles of turkcys. Proceeding Hohenheimer Geflügelsymposium. Stuttgart, pp. $115-118$

Gahne B., Juneja R.K., Gromulus J., 1977. Horizontal polyacrylamide gradient gel electrophoresis for the simultaneoues phenotyping of transferrin, posttransferrin, albumin and post-albumin in the blood plasma of cattle. Anim. Blood Groups. Biochem. Genet. 8, 127-137

Gluchowski W., Brodacki A., Rupeć Z., Wójcik A., 1985. The method of polyacrylamid gel plates hardening (in Polish). Fol. Soc. Sci. Lubl. 27, 141-143

Hartmann W., Hala K.. Heil G., Krieg R., 1986. Effect of blood group genotypes on resistance to Marek's disease in Leghorn crosses. Proceeding 7th European Poultry Conference. Paris, pp. 216-220

Jankowski J., 1989. Reaction of four turkey strains for breeding methods (in Polish). Acta Acad. Agric. Techn. Olst., Zoot. 31, Suppl. B, 3-56

Juncja K., Gahne B., Kuryl J., Gasparska J., 1982. Genetic polymorphism of the vitamin D-binding protein and a pretransferrin in chicken plasma. Hereditas 96, 89-96

Kierek-Jaszczak D., 1976. Elcctrophoretic forms of transferrin from blood serum and egg content of some selected species of poultry (in Polish). Prace Mat. Zoot. 10, 41-47

Ranjan S., Pingel H., 1973. Study of polymorphism of transferrin esterase and alkaline phosphatasc in blood serum of chicken and turkey (in Polish). Rocz. Nauk. Zoot. 2, 31-38

Schellncr H.P., 1970. Gesamteiweissbestimmung und electrophoretische Auftrennung in Polyacrylamidgel von Putenserum. Arch. Geflügelk. 2, 72-74

Sheldon B.L., 1980. Perspectives for poultry genetics in the age of molecular biology. World Poultry Sci. J. 36, 143-173

\section{STRESZCZENIE}

\section{Polimorfizm białek surowicy krwi z podregionu pretransferyn (Ptf) a wartość użytkowa indyków}

Przeprowadzono rozdziały białek surowicy krwi 232 indyczek z rodu J-11 i 242 indyczek z rodu J-22 przy pomocy elektroforczy poziomej na żelu poliakrylamidowym. Genotypy białek z podregionu pretransferyn (Ptf) umożliwily podzial samic na grupy $\mathrm{A}, \mathrm{AB}, \mathrm{i} \mathbf{B}$. W grupach określono średni poziom cech użytkowych: liczbẹ dni do dojrzałości, liczbę i masę jaj, zapłodnienie jaj, wyląg piskląt z jaj zapłodnionych i nałożonych oraz masę ciała indyczek w wicku 30 i 56 tygodni.

Indyczki o genotypach $\mathrm{Ptf}^{\mathrm{\beta}} / \mathrm{Ptf}^{\beta}$ mialy gorsze wyniki reprodukcyjne niż o pozostałych genotypach.

Mała liczebność indyków o genotypach $\mathrm{Ptf}^{\mathrm{\beta}} / \mathrm{Ptf}^{\mathrm{B}}$ w rodzie J-22 wskazuje na konieczność dalszych badań nad tymi problemami na większej liçbie osobników. 